\title{
English Career Terms Synonymy
}

\author{
Yulia A. Filyasova \\ Saint-Petersburg State University of Economics, \\ Griboyedov Canal Embankment, 30-32 A, Saint-Petersburg, Russian Federation, 191023 \\ $\bowtie$ phill.yield@gmail.com
}

\begin{abstract}
Synonymy is a linguistic phenomenon which reflects the complexity of reality representation in a linguistic worldview. Terminological synonymy poses certain difficulties for specialists who perform practical tasks in application areas such as translation and education. Career development, career advancement, career growth, career progression, career progress, career enhancement are among the most frequently used terms with similar semantics which indicates a certain degree of indefiniteness in the terminology in the correspondent professional field. The aim of this paper is to conduct comparative linguistic analysis of these terms. The material is presented by research article titles from eight scientific databases. Methods include quantitative and qualitative study of frequency, semantic fields by semantically related concepts, keywords, syntagmatic collocability and componential analysis. The results show that career development can be currently considered a hyperonym as it is the most frequent and time-proved term with the widest semantic coverage and indication to professional spheres in the dictionaries. Despite its obvious prevalence, career advancement, career progression, career growth and career progress are gaining momentum as alternative terms highlighting a lack of important semantic nuances in career development. Though the general number of career advancement and career progression across research papers is considerably lower, their presence in article titles is almost the same as that of career development. Title is arguably the most demonstrative part of a research paper; therefore, it can be presumed that the career terms might acquire lexical meanings which will clearly differentiate vertical career growth from horizontal organizational movement.
\end{abstract}

Keywords: synonymy, hyperonym, career, term, research article, componential analysis, semantic field, syntactic collocability

\section{Article history:}

Received: 01.02.2021

Accepted: 01.06.2021

\section{For citation:}

Filyasova, Yu.A. (2021). English Career Terms Synonymy. RUDN Journal of Language Studies, Semiotics and Semantics, 12(3), 669-683. doi: 10.22363/2313-2299-2021-12-3-669-683

(C) Filyasova Yu.A., 2021

This work is licensed under a Creative Commons Attribution 4.0 International License https://creativecommons.org/licenses/by/4.0/ 
УДК 811.111’373.421

\title{
Синонимия английских карьеро-ориентированных терминов
}

\author{
Ю.А. Филясова \\ Санкт-Петербургский государственный экономический университет, \\ наб. канала Грибоедова, д. 30-32, литер А, Санкт-Петербург, Российская Федераиия, 191023 \\ $\triangle$ phill.yield@gmail.com
}

\begin{abstract}
Аннотация. Синонимия - это языковое явление, показывающее сложность репрезентации реальности в языковой картине мира. Терминологическая синонимия представляет определенные трудности для специалистов, выполняющих практические задачи в прикладных областях, таких как перевод и образование. Career development, career advancement, career growth, career progression, career progress, career enhancement являются наиболее употребительными терминами с похожей семантикой, которая указывает на некоторую неопределенность терминологии в соответствующей профессиональной области. Цель данной работы - выполнить сравнительный языковой анализ перечисленных терминов. В качестве материала исследования были отобраны названия научных статей из восьми научных баз данных. Методы исследования включали количественный и качественный анализ частотности, семантических полей на основе семантически связанных понятий, ключевых слов, синтагматической сочетаемости и компонентный анализ. Результаты показывают, что career development в настоящее время можно считать гиперонимом, т.к. это наиболее частотный и проверенный временем термин с наиболее широкой семантикой и указанием на профессиональные области в словарных статьях. Несмотря на очевидную распространенность, career advancement, career progression, career growth и career progress становятся популярными как альтернативные термины, подчеркивая недостаточную способность career development в передаче оттенков значения. Хотя общее число терминов career advancement и career progression в публикациях значительно меньше, их присутствие в названиях статей почти такое же, как у career development. Название - это наиболее показательная часть публикации; следовательно, можно предположить, что рассматриваемые термины могут приобрести лексические значения, которые будут четко различать вертикальный карьерный рост и горизонтальное продвижение.
\end{abstract}

Ключевые слова: синонимия, гипероним, карьера, термин, научная статья, компонентный анализ, семантическое поле, синтаксическая сочетаемость

\section{История статьи:}

Дата поступления: 01.02.2021

Дата приема в печать: 01.06.2021

\section{Для цитирования:}

Filyasova Yu.A. English Career Terms Synonymy // Вестник Российского университета дружбы народов. Серия: Теория языка. Семиотика. Семантика. 2021. Т. 12. № 3. С. 669-683. doi: 10.22363/2313-2299-2021-12-3-669-683

\section{Introduction}

Synonymy is a linguistic phenomenon that represents complicated relationships between lexical meaning and object of reference. The latter normally has a complex nature which needs more than one linguistic sign to be represented in speech. 
Complete synonyms are rare [1] due to semantic, expressive, stylistic, syntactic features, also dialectical variations, speakers' attitudes, and origin of words [2] which differentiate doublets. Each word possesses a unique semantic field and etymology which determine its functional characteristics. Synonyms provide opportunities to describe facts, objects and phenomena of extralinguistic reality and environment in a detailed manner with preciseness and accuracy taking into consideration stylistics, register, communicative situation, speech context, modality and pragmatic subtleties [3]. Nowadays, synonymy is widely studied by means of text mining applications, such as automatic clustering of synonymous phrases [4]. Along with semantic identity and similar functions, uniformity of derivational paradigms and similarity of accentual models are also regarded as significant factors in construction of synonymous chains [5].

Synonymy is not a vitally important topic for conversational speech and normal daily interactions as it is neutralized by contextual implications and communicative background. Moreover, the scope of conversational lexis is well known; shared awareness of lexical meaning allows communicators to successfully meet communicative objectives. As opposed to commonly known vocabulary, terms pose serious difficulties for non-professional speakers. Even among professional communicators, terms have to be continuously clarified and specified in order to eliminate obscurity and ambiguity in meaning due to potential differences in views, descriptive approaches and contextual understanding. Subsequently, terms as a category of lexis are also characterized by synonymy though they are supposed to have direct connections between word, its denotatum and significatum. Linguistic criteria for terms description include nominative nature, frequency, specificity of usage, conventionality, terminological derivativeness and productivity, motivation, laconism, internationalization [6]. Term is a useful professional tool for specialists [7].

Terms is a subcategory of a language function, according to common linguistic laws. "Term is a word which belongs to a flexible, dynamic and liquid lexical system where new lexical meanings are constantly emerging" [8. P. 34]. Functional areas, such as petroleum, construction industries, engineering, design, among others, are considered to be specific for terms separating them into a particular category of words. The borderline between common lexis and terminology is not well-established, largely depending on the context and communicative situation. Cognitive differentiation of synonyms is a key to communicative success: "A lexicon associates each message with a set of states. A linguistic behavior specifies a probabilistic speaker rule (a probabilistic choice of message for each state) and a probabilistic hearer rule (a probabilistic choice of state for each message) given a lexicon" [9. P. 2762].

Lexical synonymy is closely related to another linguistic phenomenon called variation, or absolute synonymy [10]. The former considering lexical units with adjacent but still non-overlapping semantic fields does not completely coincide with the latter being typical of initial stages of field development. Deeper research 
and understanding the field is accompanied by establishment of terms with clear differentiation of meaning.

In relation to terms nominating industrial objects, it is worth noting that these are constantly changing due to upgrading, material improvement, environment transformation and other processes related to extralinguistic reality. Units of language which are derivative of these objects have to change subsequent to social and industrial processes. Many terms become obsolete and useless as they do not contain key features of new objects. New characteristics which objects of reference acquire in the course of time need nomination. Taking into consideration fast rates at which industry is currently developing, synonymy and variation are consecutive and unavoidable. "A considerable space for synonymic treatment of terms results in the detriment of their correct conceptual decoding" [11]. At a given time and within a scientific community, one term may become more popular than others: "We propose the concept of 'master term' as a keyword that not only reflects, but activates and establishes a master frame around which conversations and practices revolve" [12].

Terms can be represented by single, derivative, compound words and terminological phrases. Compound terms are considered to be the most productive due to their potential to denote complex nature of real objects [13]. Lexical synonymy among terms positively affects the semantic accuracy of terms since it ameliorates terminological meaning and beneficiates their semantic structure.

Yu.D. Apresyan distinguishes four categories of synonyms: those which completely coincide, functionally coincide, partly coincide, and are completely different [14. P. 230]. Murphy [15] defines absolute synonyms as words whose meaning and contextual functions are identical. Anagbogu et al. [16] add that absolute synonyms are contextually interchangeable. Those synonyms which are close in meaning but have denotative or significative differences are called quasi synonyms which demonstrate collocational incompatibility [17. P. 100]. Semantic classification and categorization based on dictionaries, thesauri and lexicological sources are among the main research methods of studying semantic fields of key concepts, their synonymic variations and identifying semantic cores [18 - 20]. Theoretical fundamentals based on practical research methods give evidence that analysis of synonymy should be based on semantic and syntactic studies. A complex of generalized knowledge of lexical units summarized in dictionaries and specific lexical meaning exposed in particular contextual realizations can complement each other and, in addition, expand generally known concepts with newly appearing subtleties in lexical meaning [21;22].

The aim of this paper is to study the semantics and functionality of career terms and identify the degree of their correspondence in terms of synonymy: career advancement, career development, career enhancement, career growth, career progress, and career progression. The terms are widely used in the field of management sociology, which is "a terminologically heterogeneous knowledge domain, comprising overlapping subsystems that select relevant terms through systemic relations, according to certain scientific theories, approaches, and schools" [6. P. 167]. 


\section{Material}

Title is the most exposed part of a research article; it is readily available and easily accessible to the reader. In some cases, title is the only part of an article which is available. Title gives the reader the most relevant information about the problem area of the research. Title does not contain any random pieces of information about the topic of research. Therefore, titles are viewed as the most reliable indicators of terminological functionality.

The career terms were analyzed in dictionary entries and research articles. 420 research article titles were selected by means of continuous sampling from international academic journal databases [32-39]. Those article titles which contained the target terminological phrases were included in the analysis. The terms demonstrate unequal presence in titles (Tb. 1). Career development, career advancement and career progression are the most numerous across the databases. Career growth is twice as less frequently occurring a term, followed by career progress; career enhancement is four times less frequent as a term.

Table 1 / Таблица 1

The career terms in research papers

Термины, описывающие карьеру, в научных статьях

\begin{tabular}{|c|c|c|c|}
\hline No & Terms & Article titles [32-38] & Documents [39] \\
\hline 1. & Career development & 110 & 43394 \\
\hline 2. & Career advancement & 101 & 4823 \\
\hline 3. & Career progression & 100 & 2569 \\
\hline 4. & Career growth & 48 & 6092 \\
\hline 5. & Career progress & 37 & 4518 \\
\hline 6. & Career enhancement & 24 & 977 \\
\hline \multicolumn{2}{|c|}{ Total } & $\mathbf{4 2 0}$ & $\mathbf{5 7 9 1 8}$ \\
\hline
\end{tabular}

The terms are compound, characterized by binomiality, consisting of two unrelated words which acquire professional meaning when used together. The denotatum and significatum of the terms are not completely settled or stable due to active processes of social change and transformation in the modern society. Specifically, career is currently viewed not only in the vertical, but also horizontal meaning. Therefore, the difficulty of comparing the terms by their semantics is caused by the obscure denotative meaning of the basic term itself. A.A. Ufimtseva calls such words - nominations of unique and unreal objects of reference [23. P. 124] — those which do not have a direct material denotatum. According to the obtained statistics, 'career development' can be regarded as an umbrella term, or hyperonym. However, further semantic and syntactic analysis is needed.

\section{Methodology}

Quantitative data showing the number of research documents containing the career terms and their frequency and relations with other keywords on the basis of 
their bibliographic data were obtained from the database [39]. Lexical semantics of the terms was studied by means of componential analysis, contextual semantic analysis and syntactic collocability analysis. Firstly, definitions of the terms' compound elements were studied in four English dictionaries [28-31], and their key semes were compared. Secondly, seven scientific databases [32-38] were searched for research article titles by means of the terms as keywords. Concepts related to career terms in contextual realizations were identified in each title and classified into three broad categories for each term: personal, organizational and societal levels. Thirdly, syntactic collocability was examined with the neighbouring lexical units in the left and right contexts in terms of morphological categories.

\section{Results}

All of the career terms under analysis demonstrate similar growing dynamics in frequency, beginning with sluggish growth in the 1970s (career development, career advancement, career progress and career growth), 1980s (career enhancement), 1990s (career progression) followed by exponential surge which started in 2000 (for career development and career growth), 2002 (career advancement), 2003 (career progression), 2004 (for career enhancement and career progress) (Fig. 1).

The analysis of bibliographic data containing the career terms in [39] with the help of VOSviewer showed their most frequent connections with related concepts. Career development, in the range 2015-2018, has close relations with the most recent keywords 'education' and 'human experiment', followed by earlier 'professional development' and gender issues at the beginning of the analyzed period.

The most frequent words related to career advancement range between 2017 and 2018 (Fig. 2). The most recent words include 'career', 'leadership', 'adult', and 'human experiment'. Important issues concern gender differences, education and career mobility.

Variation timespan of the most frequently occurring words characterizing career growth includes one year - 2018. Similarly to career advancement, gender issues and human experiments are currently relevant, along with 'employment', 'education' and 'students'.

Timespan of the term career progression lasts between 2014 and 2017. It can be noted that in 2018 it wasn't as popular as career advancement or career growth. Gender issues, education and career mobility make up the semantic field for that period.

Keyword association of the term career progress falls within the timeline between 2017 and 2018; it has a clear distinction of related words into three periods: gender differences, education and student professionalization. The latter association forms common ground with the term career growth.

Career enhancement seems to be obsolete as it was intensively used between 2010 and 2012. 'Students' and 'professional education' refer to the earlier part of the period, while the later period is characterized by gender differences. 


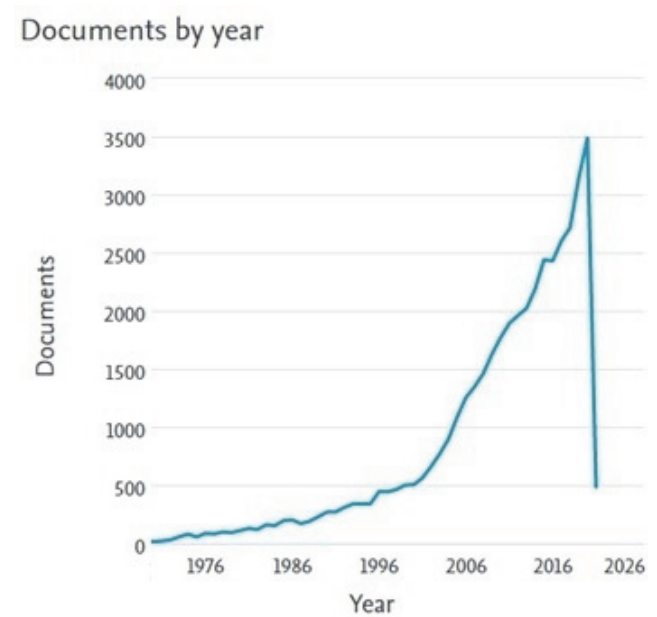

1.1. Career development

Documents by year

500

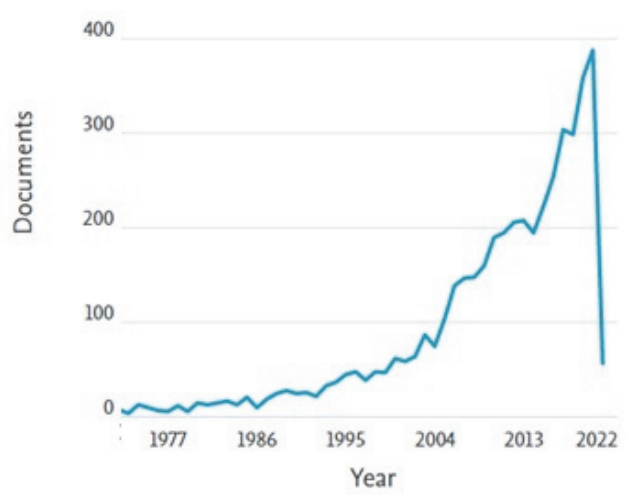

1.3. Career progress

Documents by year

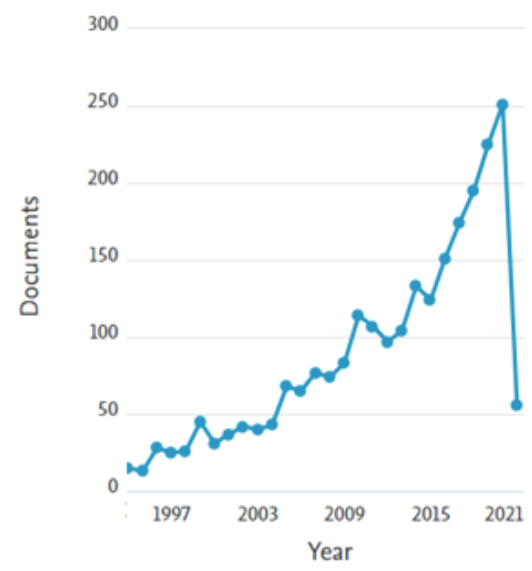

1.5. Career progression
Documents by year

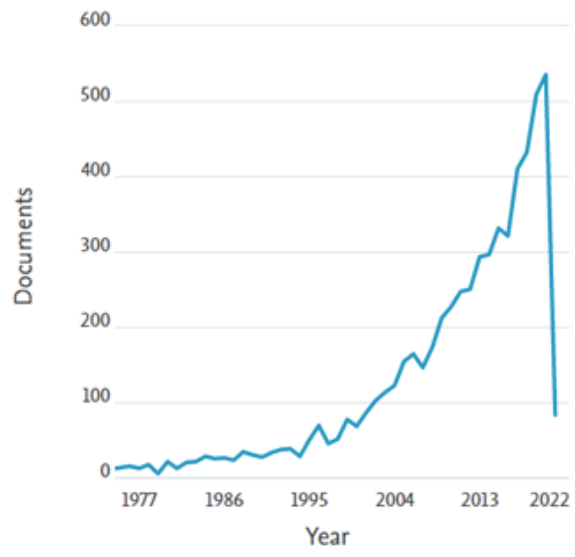

1.2. Career growth

Documents by year

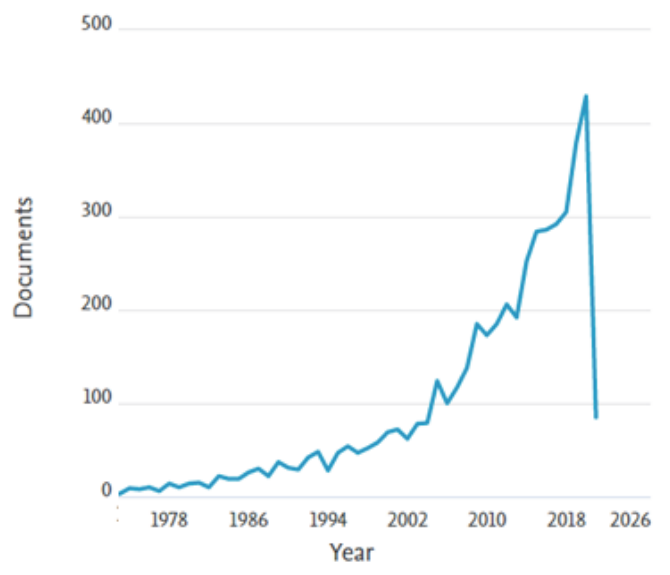

1.4. Career advancement

Documents by year

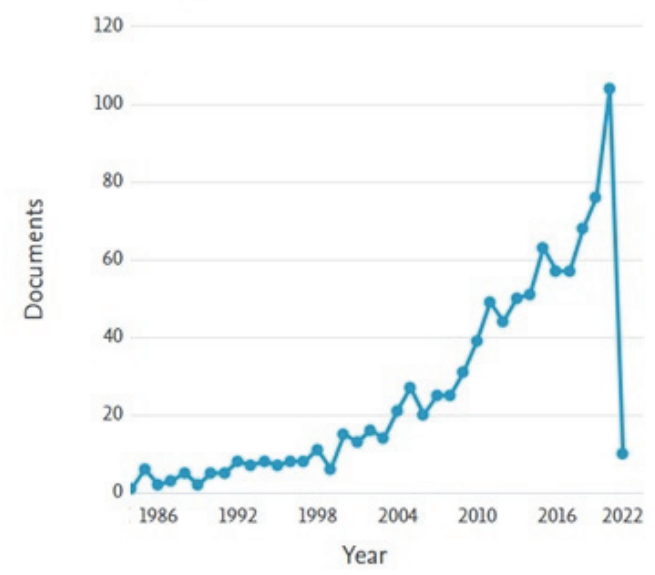

1.6. Career enhancement

Fig. 1. Documents containing the career terms in the database [39] 
To sum up, all of the terms consider education and gender as the key issues of career. Career mobility, students, professional aspects, engineering and human experiments constitute the second most frequently used keywords which differentiate their semantics.

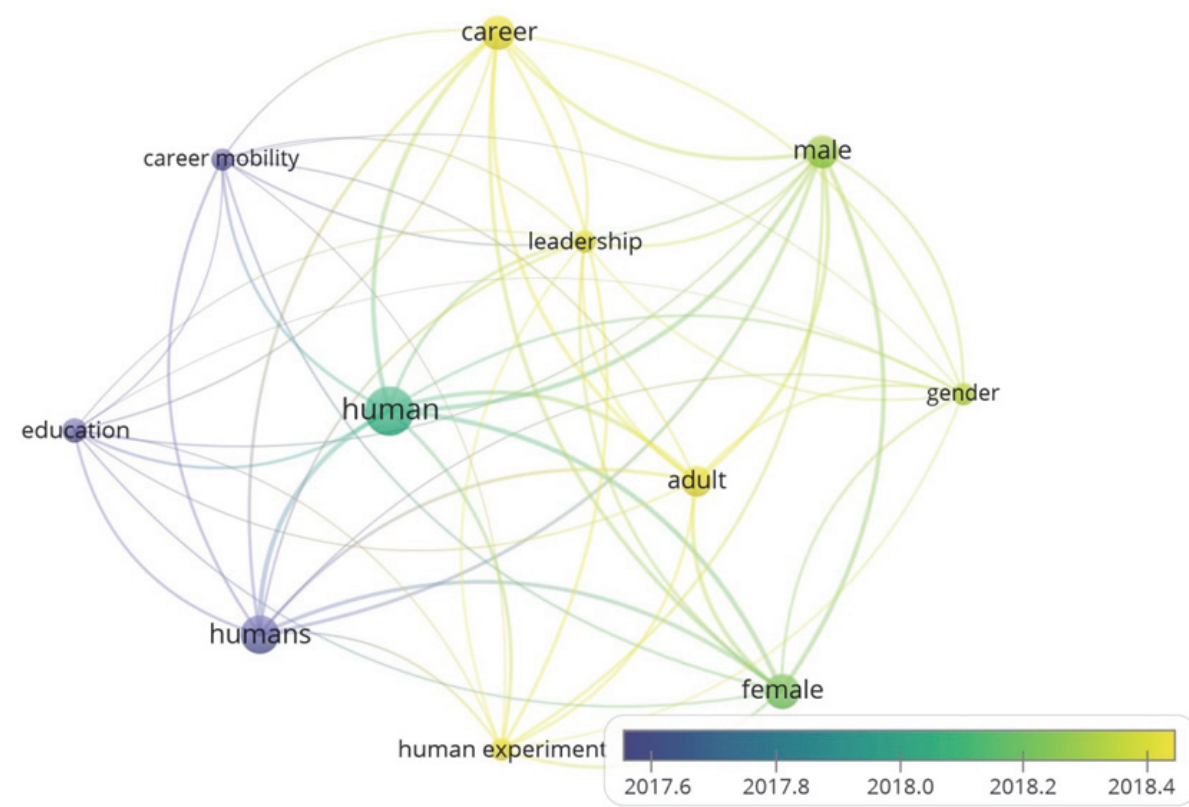

Fig. 2. Keyword occurrence for the term 'career advancement'

Рис. 2. Сочетаемость ключевого слова для термина "карьерный рост"

The lexeme career ( $\mathrm{Tb}$. 2) is defined as job (work done regularly for earning money), profession (job requiring skills, qualifications, and related to high social status), and field (work related again to high social status) [30]. Therefore, career is a complex concept which combines such semes as work, money, and status. The general meaning of the constituent elements (2-7: Tb. 2) is almost identical, coinciding in many aspects and demonstrating an upward trend towards a higher virtual goal or accumulation of tangible and intangible benefits. They have overlapping semantics across dictionaries: each of the terms is defined with key semes of the other terms under analysis. Common semantic components are improvement, change, increase, achievement. Judging by the given examples, career development and career advancement seem to be more career-specific terms.

It is obvious that "sense relations are not enough to explain the relation between some lexical items. For example, we cannot explain the relation between patient and hospital through synonymy, antonym, hyponymy, polysemy or homonymy, but we can say that they belong to the same semantic field which we can label as 'health"' [24]. The sematic relations in 420 research article titles were analyzed in order to understand the scope of the semantic field for each career term (Tb. 3). All related notions were divided into three broad categories: personal, organizational and societal. At the personal level, important topics include education, health, family, emotional balance, personality types, personal career 
choice. At the organizational level, such issues as personnel training and development, work commitment, personnel appraisal, ROI, performance, motivation, socialization and barriers are considered. Societal level concerns people with disabilities, women, young adults, students, social minorities, common health issues, market conditions, social networks, ecology, among others.

Table 2 / Таблица 2

Dictionary definitions of the term elements Дефиниции элементов терминологических сочетаний

\begin{tabular}{|c|c|}
\hline $\begin{array}{l}\text { Terminological } \\
\text { elements }\end{array}$ & Definitions \\
\hline 1. career & $\begin{array}{l}\text { - a job that you do for a long period of your life and that gives you the } \\
\text { chance to move to a higher position and earn more money [28]; } \\
\text { - a job or profession that you have been trained for, and which you do } \\
\text { for a long period of your life [29]; } \\
\text { - a job or series of related jobs that you do, especially a profession that } \\
\text { you spend a lot of your working life in [30]; } \\
\text { - a profession for which one trains and which is undertaken as a } \\
\text { permanent calling [31]; } \\
\text { - a field for or pursuit of consecutive progressive achievement especially } \\
\text { in public, professional, or business life [31] }\end{array}$ \\
\hline 2. development & $\begin{array}{l}\text { - the process of growing, changing, or becoming more advanced [28]; } \\
\text { - the process of gradually becoming bigger, better, stronger, or more } \\
\text { advanced [29]; } \\
\text { - change, growth, or improvement over a period of time [30]; } \\
\text { - the act, process, or result of developing [31] } \\
\text { e.g. professional / personal development; economic / industrial / } \\
\text { business development }\end{array}$ \\
\hline 3. advancement & $\begin{array}{l}\text { - progress [28]; } \\
\text { - progress or development in your job, level of knowledge [29]; } \\
\text { e.g. career advancement } \\
\text { - progress in your career [30]; } \\
\text { - promotion or elevation to a higher rank or position [31]; } \\
\text { - progression to a higher stage of development [31] }\end{array}$ \\
\hline 4. growth & $\begin{array}{l}\text { - the process of growing, increasing, or developing [28]; } \\
\text { - an increase in amount, number, or size; an increase in the value of } \\
\text { goods or services produced and sold by a business or a country [29]; } \\
\text { - an increase in the number, size, or importance of something [30]; } \\
\text { - progressive development: evolution [31]; } \\
\text { - increase, expansion [31] }\end{array}$ \\
\hline 5. progression & $\begin{array}{l}\text { - a change to the next stage of development [28]; } \\
\text { - a gradual process of change or development [29]; } \\
\text { - gradual change or development [30]; } \\
\text { - the action or process of progressing: advance [31]; } \\
\text { - a continuous and connected series: sequence [31] }\end{array}$ \\
\hline 6. progress & $\begin{array}{l}\text { - development and improvement of skills, knowledge, etc [28]; } \\
\text { - the process of getting better at doing something, or getting closer to } \\
\text { finishing or achieving something [29]; } \\
\text { - the process of developing or improving [30]; } \\
\text { - a forward or onward movement (as to an objective or to a goal): advance [31]; } \\
\text { - gradual betterment [31] }\end{array}$ \\
\hline 7. enhancement & $\begin{array}{l}\text { - improvement [28]; } \\
\text { - improvement [29]; } \\
\text { - the process of improving something [30]; } \\
\text { - increase or improvement in value, quality, desirability, or attractiveness } \\
\text { [31] }\end{array}$ \\
\hline
\end{tabular}


General overview of the related terms showed connection of the career terms with such fields as (1) higher education: students, faculty, professional skills, qualifications; (2) medicine: specific medical workers; (3) general work environment: employment, job satisfaction, personnel turnover, personnel assessment; (4) social issues: inequality, barriers, gender, race, ethnicity, health. IT specialists, engineers and lawyers are of rare occurrence.

Syntagmatic collocability is one of the key indicators of lexical semantics since words function only in context. Linguistic meaning of a word as an intrinsic characteristic determines its syntactic relations in speech. Syntactic collocability as a field of practical research gives evidence of valency — a linguistic category [25. P. 30]. Context is made up of morphological elements and syntactic constructions. Collocability is determined by narrow, broad and situational context.

The research article titles are characterized by nominative syntactic structures [26]. Syntactic structures were divided into six categories according to their frequency. Non-prepositional structures are the most numerous: it constitutes $41 \%-54 \%$ among all structure. Career progress is the only term that falls out of the trend, having prevalent right prepositional structures (43\%), for example:

- Non-prepositional: Exploring the Factors Affecting Career Advancement Opportunities for Women Executives in the Service Sector (Gerund CA Noun).

- Non-prepositional: National Career Development Strategy (Adj. CD Noun).

- Non-prepositional: Managers' Assessments of Employees' Organizational Career Growth Opportunities: The Role of Extra-Role Performance, Work Engagement, and Perceived Organizational Commitment (Adj. CG Noun).

- Non-prepositional: Professional Coaching: An Innovative and Promising Leadership Development and Career Enhancement Approach for Public Health Professionals (CE Noun).

- Right prepositional: The Contributions of Emotional Intelligence and Social Support for Adaptive Career Progress Among Italian Youth (Adj. CP Prep.).

The second frequent syntactic construction is by far less homogeneous than the prevalent structure: right prepositional for career progression (48\%) and career advancement (39\%); non-prepositional for career progress (35\%) and career enhancement' (42\%), left prepositional for career development (27\%); left prepositional (27\%) and attributive $(27 \%)$ for career growth, for example:

- Right prepositional: Rising to the Top: Career Progression of Women Senior-Level Student Affairs Administrators (CP Prep.).

- Right prepositional: Women Career Advancement in Public Service: A Study in Indonesia (Noun CA Prep.).

- Non-prepositional: Deus ex machina? Career progress and the contingent benefits of knowledge management systems (CP Conj.).

- Non-prepositional: Raising the Bar: Addressing Job Satisfaction Through the Development of an Achievement-Based Career Advancement Program (NounAdj. CA Noun).

- Left prepositional: A Crisis in Career Development: Life Designing and Implications for Transition (Prep. CP).

- Attributive: The Effects of Part-Time Employment and Gender on Organizational Career Growth (Adj. CG). 


\section{Семантические поля, описывающие условия реализации карьеры}

\begin{tabular}{|c|c|}
\hline $\begin{array}{l}\text { Career } \\
\text { development }\end{array}$ & $\begin{array}{l}\text { Personal level: education (3); ability (2); whole-life approach; chance (2); } \\
\text { spirituality (2); kindness; family; personality (5); effort; success } \\
\text { Organizational level: organizations (3); motivation; applications; } \\
\text { performance appraisal; approaches; strategy; program (3); ROI; measures } \\
\text { (2); culture (2); relations; mentoring (6); learning; leadership; skills (4); } \\
\text { knowledge; courses (2); services (3); occupational therapy; job satisfaction } \\
\text { (2); social media; HR; personnel; football; teachers (4); professors (3); } \\
\text { statisticians; technology workers } \\
\text { Societal level: social justice (2); crisis; public policy; persons with } \\
\text { disabilities (8); COVID-19; social inclusion; students (19); children (6); } \\
\text { women (6); gender (2); immigrants (2) }\end{array}$ \\
\hline $\begin{array}{l}\text { Career } \\
\text { advancement }\end{array}$ & $\begin{array}{l}\text { Personal level: education (4); career skills (2); narcissism; work life; health } \\
\text { Organizational level: executives (6); mentorship (5); strategy (3); low- } \\
\text { wage workers (3); job hunt (2); ambition (2); job performance (2); } \\
\text { organizational commitment (2); job satisfaction; barriers (3); trust (2); } \\
\text { leadership (2); workplace romance; etiquette; faculty (8); psychologists; } \\
\text { medical workers (9); engineers (4); research; cybersecurity } \\
\text { Societal level: persons with disabilities (8); social capital; culture; social } \\
\text { inequality (2); labor legislation, market demand; women (31); gender (3) }\end{array}$ \\
\hline $\begin{array}{l}\text { Career } \\
\text { progression }\end{array}$ & $\begin{array}{l}\text { Personal level: health (3); personality traits and values; marital status; } \\
\text { higher education; undergraduates; career choices } \\
\text { Organizational level: planning; behavioural modelling; organisational } \\
\text { barriers; the best portfolio; job mobility; job satisfaction; mentoring (2); } \\
\text { apprenticeships; training (2); doctors; librarians; clients; cricketers'; } \\
\text { headship; entrepreneurs; medicine; surgeons (5); nurses (6); therapists; } \\
\text { dietitians; physiotherapists'; gynaecology; legal profession (2); } \\
\text { radiographers; football (3); accountants'; athletic directors; academics (7); } \\
\text { IT (2) } \\
\text { Societal level: network (2); community sector (2); market forces (2); } \\
\text { politics; modernizing; ecology; social inequality (10); covid-19; criminals } \\
\text { (2); public opinion; science careers (3); ethnic minority (6); women (20); } \\
\text { gender (4) }\end{array}$ \\
\hline Career growth & $\begin{array}{l}\text { Personal level: personality (4); work attitudes (3); careerist orientation (3); } \\
\text { stress; competency (2); knowledge; job search; job loss (2) } \\
\text { Organizational level: organization (7); organizational socialization (2); } \\
\text { commitment (6); support; turnover (5); company barriers (3); leadership; } \\
\text { motivation; women (4); nurses (5); faculty (2); culture; librarians } \\
\text { Societal level: gender (2); opportunities; engineering students (2); } \\
\text { technical education (3); students; repatriate; the web }\end{array}$ \\
\hline $\begin{array}{l}\text { Career } \\
\text { progress }\end{array}$ & $\begin{array}{l}\text { Personal level: vocational identity; overeducation; self-efficacy; } \\
\text { qualification } \\
\text { Organizational level: emotional intelligence; nursing (3); anaesthesia; } \\
\text { surgical; commitment; work satisfaction; knowledge; turnover; } \\
\text { management (4); leadership; academics (2); competence assessment; } \\
\text { employability; professionals; athletes } \\
\text { Societal level: social support; youth (3); gender differences; women (8); } \\
\text { geographical mobility; gender issues (4); academic systems; social capital; } \\
\text { graduates (2); scholars; race (2); digital skills; nursing; learning } \\
\text { environment; students; social barriers (2) }\end{array}$ \\
\hline $\begin{array}{l}\text { Career } \\
\text { enhancement }\end{array}$ & $\begin{array}{l}\text { Personal level: personal development; work life } \\
\text { Organizational level: professional coaching (5); leadership; professional } \\
\text { competence (3); professional certification; academy; teacher (3); faculty; } \\
\text { diversifying profession; poultry processing } \\
\text { Societal level: women (2); public health; undergraduates }\end{array}$ \\
\hline
\end{tabular}


Table 4 / Таблица 4

Syntactic collocability, \%, of the career terms

Синтаксическая совместимость терминов, \%, описывающих карьеру

\begin{tabular}{|c|c|c|c|c|c|c|}
\hline $\begin{array}{c}\text { Syntactic } \\
\text { structures }\end{array}$ & $\begin{array}{c}\text { Career } \\
\text { development }\end{array}$ & $\begin{array}{c}\text { Career } \\
\text { advancement }\end{array}$ & $\begin{array}{c}\text { Career } \\
\text { progression }\end{array}$ & $\begin{array}{c}\text { Career } \\
\text { Growth }\end{array}$ & $\begin{array}{c}\text { Career } \\
\text { Progress }\end{array}$ & $\begin{array}{c}\text { Career } \\
\text { enhancement }\end{array}$ \\
\hline $\begin{array}{c}\text { Non- } \\
\text { prepositional }\end{array}$ & 45 & 44 & 41 & 54 & 35 & 42 \\
\hline $\begin{array}{c}\text { Right } \\
\text { prepositional }\end{array}$ & 17 & 39 & 48 & 23 & 43 & 13 \\
\hline $\begin{array}{c}\text { Left } \\
\text { prepositional }\end{array}$ & 27 & 22 & 19 & 27 & 24 & 46 \\
\hline $\begin{array}{c}\text { Possessive } \\
\text { nominative }\end{array}$ & 7 & 15 & 14 & 13 & 5 & 8 \\
\hline Attributive & 5 & 9 & 14 & 27 & 19 & 0 \\
\hline Verbal & 5 & 7 & 11 & 4 & 5 & 0 \\
\hline
\end{tabular}

\section{Conclusion}

The six career terms considered in the paper have//belong to similar semantic fields but have different frequency of occurrence in research documents and article titles. The obtained results can be used in different application areas, such as professional thesaurus complication, translation and teaching practice. Co-existence of several alternative terms might show their intention to differentiate vertical movement along a hierarchical organizational structure from horizontal, lateral move.

Career development seems to be a hyperonym for the considered terms since it is among the most frequently occurring terms in research article titles across all databases, and by far the most numerous term used in the Scopus database (39). It was among the first terms which appeared in research articles — in the 1970s and had an early take off in 2000. Due to its prevalent quantitative presence in research papers, it has the widest semantics. Dictionaries mention its connection to professional business areas. Its main syntactic structures are non-prepositional and left prepositional constructions.

Career advancement and career progression are almost as frequent as career development in research article titles, however, they are significantly less numerous in research papers, even less numerous than career growth across research documents. It is worth noting that career progression is the latest among all terms under consideration since it became popular only in the 1990s. As for collocability, career advancement and career progression have similar occurrence in nonprepositional and right prepositional syntactic structures. Both of them have career mobility as a frequent keyword. However, advancement has indication of careerrelated progress in dictionaries.

Career growth is about $20 \%$ a more frequently used term than career progress, but in comparison with the other terms, they have a similar occurrence both in research article titles and research papers. Analysis of bibliographic data shows that they have more links with professional aspects of career. In terms of collocability, career growth has a wider valency potential showing frequent syntactic occurrence 
in right, left prepositional and attributive structures; while career progress tends towards right and non-prepositional structures. Generally, career growth is syntactically a multifunctional term.

Career enhancement seems to be currently losing its popularity though it became frequent in the $1980 \mathrm{~s}$ - earlier than career progression. Syntactically, its collocability is similar to career development. It should be mentioned that it has no collocations in attributive or verbal structures.

\section{References}

1. Lemov, A.V. (2015). Whether doublets-synonyms are identical or not. Historical and social educational ideas, 7(3), 211-213. (In Russ.).

2. Alomoush, O.I.S. (2016). Synonymy in Jordanian Arabic. Advances in Language and Literary Studies, 7(3), 243-247.

3. Litvinova, L.A. (2016). Functions of synonyms in language. Innovative Science, 6(3), 128-131. (In Russ.).

4. Nguyen, N.T.H., Miwa, M., Tsuruoka, Y. \& Tojo, S. (2015). Identifying synonymy between relational phrases using word embeddings. Journal of Biomedical Informatics, 56, 94-102.

5. Zubkova, L.G. \& Karavaeva, E.M. (2008). Typology of verbal synonymous rows in the plan of expression. Scientific notes of KGU, 150(2), 219-227. (In Russ.).

6. Maikova, T.A. (2016). Basic criteria for terminology selection in compiling lexicographic model of sociological terminology in English. RUDN Journal of Language Studies, Semiotics and Semantics, 2, 165-174. (In Russ.).

7. Kalugina, Ju.E. (2020). Analysis of Country Specific Terminological Units in Economics from English Sources. RUDN Journal of Language Studies, Semiotics and Semantics, 11(3), 517—531. (In Russ.).

8. Saprykina, O.A. (2016). Term as a phenomenon of language and of culture (history of words and concepts). RUDN Journal of Language Studies, Semiotics and Semantics, 2, 165-174. (In Russ.).

9. Brochhagen, T., Franke, M. \& van Rooij, R. (2018). Coevolution of lexical meaning and pragmatic use. Cognitive Science: A Multidisciplinary Journal, 42, 2757-2789.

10. Okeke, G.T., Mbah, B.M. \& Okeke, Ch.O. (2020). Re-Examination of Synonymy in the Standard Igbo. SAGE Open, 10(1), 21582440209.

11. Bednárová-Gibová, K. (2019). Synonymic Traps in Selected English Lexical Semantics Terms. RUDN Journal of Language Studies, Semiotics and Semantics, 10(4), 754-760.

12. Stevens, T.M., Aarts, N., \& Dewulf, A. (2019). The emergence and evolution of master terms in the public debate about livestock farming: Semantic fields, communication strategies and policy practices. Discourse, Context and Media, 31, 100-317.

13. Soluyanova, E. (2014). Synonymy of machine building terms. Izvestiya MGTU “MAMI", 1, 237-240. (In Russ.).

14. Apresyan, Yu.D. (1974). Lexical semantics: synonymous language means. Moscow. (In Russ.).

15. Murphy, M.L. (2003). Semantic relations and the lexicon. Cambridge: University Press.

16. Anagbogu, P.N., Mbah, B.M., \& Eme, C.A. (2010). Introduction to linguistics. Amaka Dreams.

17. Kobozeva, I.M. (2000). Linguistic semantics. Moscow: URSS. (In Russ.).

18. Denisenko, V.N. \& Leksina, I.A. (2016). Psycholinguistic characteristicsof the verbs of emotional 5 evaluative relations. RUDN Journal of Language Studies, Semiotics and Semantics, 3, 130-136. (In Russ.).

19. Boholm, M. (2017). The semantic field of risk. Safety Science, 92, 205-216.

20. Filyasova, Yu.A. (2019). The English Economic Term 'Human Capital' and Its Semantic Field in Scientific Discourse. RUDN Journal of Language Studies, Semiotics and Semantics, 10(3), $700-713$. 
21. Filyasova, Yu.A. (2019). Effectiveness vs. efficiency: an analysis of valency and collocability in a technical context. RUDN Journal of Language Studies, Semiotics and Semantics, 10(1), $187-196$.

22. Yang, B. (2016). A Corpus-Based Comparative Study of "Learn" and "Acquire". English Language Teaching, 9(1), 209-220.

23. Ufimtseva, A.A. (1986). Lexical meaning. Moscow: Nauka. (In Russ.).

24. Boran, G. (2018). Semantic Fields and EFL/ESL Teaching. International Online Journal of Education and Teaching, 5(2), 391-399.

25. Vlavatskaya, M.V. (2009). Combinatorial semasiology (semantics and word combinability). $M N K O, 7(2), 29-34$. (In Russ.).

26. Filyasova, Yu.A. (2020). A Linguistic Analysis of Petroleum-Related English Research Article Titles. RUDN Journal of Language Studies, Semiotics and Semantics, 11(1), 120-134.

27. Liu, D. \& Zhong, Sh. (2016). L2 vs. L1 Use of Synonymy: An Empirical Study of Synonym Use/Acquisition. Applied Linguistics, 37(2), 239-261.

\section{Dictionaries}

1. Cambridge Dictionary. URL: https://dictionary.cambridge.org/ru/ (accessed: 30.01.2021).

2. Longman Dictionary of Contemporary English. URL: https://www.ldoceonline.com/ (accessed: 30.01.2021).

3. Macmillan Dictionary. URL: https://www.macmillandictionary.com/ (accessed: 30.01.2021).

4. Webster Dictionary. URL: https://www.merriam-webster.com/ (accessed: 30.01.2021).

\section{Sources}

1. 32. ERIC. URL: https://eric.ed.gov/ (accessed: 30.11.2020).

2. IEEE Xplore. URL: https://ieeexplore.ieee.org/ (accessed: 30.11.2020).

3. JSTORE. URL: https://www.jstor.org/ (accessed: 30.11.2020).

4. SAGE. URL: https://journals.sagepub.com/ (accessed: 30.11.2020).

5. Science Direct. URL: https://www.sciencedirect.com/ (accessed: 30.11.2020).

6. The Directory of Open Access Journals. URL: https://doaj.org/ (accessed: 30.11.2020).

7. Wiley. URL: https://onlinelibrary.wiley.com/ (accessed: 30.11.2020).

8. Scopus. URL: https://scopus.com (accessed: 30.11.2020).

\section{Библиографический список}

1. Лемов А.В. Тождественны ли дублеты-синонимы? // ИСОМ. 2015. № 3. С. 211-213.

2. Alomoush O.I.S. Synonymy in Jordanian Arabic // Advances in Language and Literary Studies. 2016. Vol. 7 (3). P. $243-247$.

3. Литвинова Л.А. Функции синонимов в языке // Инновационная наука. 2016. № 6-3. C. $128-131$.

4. Nguyen N.T.H., Miwa M., Tsuruoka Y., Tojo S. Identifying synonymy between relational phrases using word embeddings // Journal of Biomedical Informatics. 2015. Vol. 56. P. 94-102.

5. Зубкова Л.Г., Караваева Е.М. Типология глагольных синонимических рядов в плане выражения // Уч. записки КГУ. 2008. Т. 150. Кн. 2. С. 219-227.

6. Майкова Т.А. Основные критерии отбора терминологической лексики при разработке лексикографической модели англоязычной терминологии социологии // Вестник Российского университета дружбы народов. Серия: Теория языка. Семиотика. Семантика. 2016. T. 7. № 2. С. $165-174$.

7. Калугина Ю.Е. Анализ национально-маркированных терминологических единиц экономики на материале английского языка // Вестник Российского университета дружбы народов. Серия: Теория языка. Семиотика. Семантика. 2020. Т. 11. № 3. С. 517—531. 
8. Сапрыкина O.A. Термин как феномен языка и культуры (к истории слов и понятий) // Вестник Российского университета дружбы народов. Серия: Теория языка. Семиотика. Семантика. 2017. Т.8. № 1. С. 33-39.

9. Brochhagen T., Franke M., van Rooij R. Coevolution of lexical meaning and pragmatic use // Cognitive Science: A Multidisciplinary Journal. 2018. Vol. 42. Pp. 2757-2789.

10. Okeke G.T., Mbah B.M., Okeke Ch.O. Re-Examination of Synonymy in the Standard Igbo // SAGE Open. 2020. Vol. 10 (1). P. 21582440209.

11. Беднарова-Гибова К. Синонимы-ловушки отдельных терминов лексической семантики английского языка // Вестник Российского университета дружбы народов. Серия: Теория языка. Семиотика. Семантика. 2019. Т. 10. № 4. С. 754-760.

12. Stevens T.M., Aarts N., Dewulf A. The emergence and evolution of master terms in the public debate about livestock farming: Semantic fields, communication strategies and policy practices // Discourse, Context and Media. 2019. Vol. 31. P. 100-317.

13. Солуянова Е.Г. Синонимия машиностроительных терминов // Известия МГТУ. 2014. № 1. С. $237-240$.

14. Апресян Ю.Д. Лексическая семантика: синонимические средства языка. М., 1974.

15. Murphy M.L. Semantic relations and the lexicon. CUP, 2003.

16. Anagbogu P.N., Mbah B.M., Eme C.A. Introduction to linguistics. Amaka Dreams, 2010.

17. Кобозева И.М. Лингвистическая семантика. М.: Эдиториал УРСС, 2000.

18. Денисенко В.Н., Лексина И.А. Психолингвистическая характеристика глаголов эмоционально-оценочных отношений // Вестник Российского университета дружбы народов. Серия: Теория языка. Семиотика. Семантика. 2016. Т. 7. № 3. С. 130-136.

19. Boholm M. The semantic field of risk // Safety Science. 2017. Vol. 92. P. 205-216.

20. Филясова Ю.А. Английский экономический термин «человеческий капитал» и его семантическое поле в научном дискурсе // Вестник Российского университета дружбы народов. Серия: Теория языка. Семиотика. Семантика. 2019. Т. 10. № 3. С. 700-713.

21. Филясова Ю.А. Effectiveness vs. efficiency: анализ валентности и сочетаемости в техническом контексте // Вестник Российского университета дружбы народов. Серия: Теория языка. Семиотика. Семантика. 2019. Т. 10. № 1. С. 187-196.

22. Yang B. A Corpus-Based Comparative Study of "Learn" and "Acquire" // English Language Teaching. 2016. Vol. 9 (1). P. 209-220.

23. Уфимщева А.А. Лексическое значение. М.: Наука, 1986.

24. Boran G. Semantic Fields and EFL/ESL Teaching // International Online Journal of Education and Teaching. 2018. Vol. 5 (2). P. 391-399.

25. Влавацкая М.В. Комбинаторная семасиология (семантика и сочетаемость слов) // МНКО. 2009. № 7-2. C. $29-34$.

26. Филясова Ю.А. Лингвистический анализ английских названий научных статей по нефтегазовой тематике // Вестник Российского университета дружбы народов. Серия: Теория языка. Семиотика. Семантика. 2020. Т 11. № 1. С. 120-134.

27. Liu D., Zhong Sh. L2 vs. L1 Use of Synonymy: An Empirical Study of Synonym Use/Acquisition // Applied Linguistics. 2016. Vol. 37(2). P. 239-261.

\section{Информация об авторе:}

Филясова Юлия Анатольевна, кандидат филологических наук, доцент кафедры английской филологии и перевода Санкт-Петербургского государственного экономического университета; научные интересы: лингвистика, фонетика, деловой английский язык, медиадискурс, технический перевод, педагогика; e-mail: phill.yield@gmail.com SPIN-код: 9503-8000

\section{Information about the author:}

Yulia A. Filyasova, PhD of Philological Sciences, Associate Professor of the Department of English Philology and Translation, Saint-Petersburg State University of Economics; research interests: Linguistics, Phonetics, Business English, Media discourse, Technical translation, Pedagogy; e-mail: phill.yield@gmail.com ORCID 0000-0002-9728-9458 